\title{
The XIXth International Geological Congress, Algiers, 1952
}

8 rue Charles-Lefebvre, F 77210 Avon, France.

The Algiers Congress came between the one held in London in 1948 (see Trümpy, 2004) and the one in Mexico (1956). It was the second in Africa, after the one in Pretoria, South Africa (1929). The plenary meeting was held in Algiers between 8 and 15 September, 1952. It brought together 1,129 participants (from the 2,910 who registered), coming from 82 countries. The Presidency was held by Professor Charles Jacob, a Member of the Académie des Sciences (Paris). The position of Secretary-General was in the safe hands of Robert Laffitte, Professor in the Faculty of Science at the University of Algiers. The scientific sessions had 17 sections. In addition to a cruise excursion held before the Congress there was a total of 44 excursions held before and after the Algiers meeting in the territories then under French administration: Algeria, Morocco, Tunisia, and the dependencies of the Sahara region and West Africa.

\section{The choice of Algiers}

The selection process had a long history. At the XVII Congress in Moscow (see Malinovsky, 2004), in the days of the Soviet Union, the leader of the French delegation, Charles Jacob, said on 22 July, 1937, that he had "the honour to make the preliminary proposal to convene the XVIII Session [of the Congress] in French North Africa", but "he could not consider it final [because the] ... proposal had not yet [been] authorized by the French Government". The following day, two official proposals were presented for the next Congress, one from the Geological Society of London, and the other from Japan. The political situation evidently influenced the choice, which on 28 July was made in favour of London (65 votes), with Tokyo only receiving 5 votes. Before the scrutiny of the votes, Professor Jacob indicated that "the French delegation [would] ... vote in favour of the British invitation". We thus had the Entente Cordiale between the two major European democracies, which, however, were at that time flirting with the USSR. The Russians voted openly for London.

The World War of 1939-1945 and its aftermath accounted for the fact that the XVIII Congress was delayed until the summer of 1948. The Congress Council then had two candidates for hosting the next Session: Algeria "on the invitation of the Government of France and [the] Governments of the French Territories in North Africa" and India, which was at that time administered by Great Britain. The head of the French delegation in London, Léon Lutaud, asked for the minutes of the Moscow meeting to be read. The reading recalled the fact that at that meeting France had proposed Algeria for the XVIII Congress, but it had subsequently stood aside in favour of London. Divided between its two wartime allies, the United States offered no opinion. On the word of Vladimir Beloussov, the USSR was quite happy to vote in favour of the French proposal, and the Belgian and Swiss delegations leaned strongly towards the choice of Algeria. On
30 August, by a show of hands, which minimized any bad feeling, the decision was adopted. For practical reasons, it was agreed that the Algiers Congress would be held four years later, that is to say in 1952. This new four-year interval became the rule thenceforth.

\section{The situation of geology in North Africa in $\mathbf{1 9 5 2}$}

Algeria already had a long geological tradition. Among the troops who, in 1830, launched the conquest of the "Regency of Algiers" (which theoretically was a dependency of the Ottoman Empire) was a geologist Captain A. Rozet, who had played an important role in the Société Géologique de France, founded in Paris that year. Later in 1839, a "scientific commission", which had E. Renou as geologist, was charged with drawing up a preliminary inventory of Algeria. Subsequently, a geological survey was established in 1883, under the aegis of the Mining Survey of Algeria (1842). As for the Algiers École Supérieure des Sciences (1879), it was later to become the Faculty of Science of the University of Algiers (founded in 1909). The collaboration of the heads of these two organizations (J. Pouyanne and A. Pomel) went back to the publication, in 1882, of the first edition of a general geological map of Algeria on a scale of $1: 800,000$. A second, completed, and integrated edition followed in 1889 , before the third and last edition of 1900 .

The development of regional studies was to see a long-standing rivalry between the academics of Algiers and their colleagues from France. Two meetings of the Société Géologique de France (especially that of 1924), which laid the groundwork for the geology of northern Algeria, showed that the geological study of that country was already as advanced as that in many parts of Europe. Tunisia and Morocco began to be studied following the instauration of the 'protectorates' in 1881 and 1912 respectively. This was essentially thanks to the efforts of the active geological surveys, linked to the administration of the Mining Surveys, but also to the work of the European academics, particularly from France. Thus a complete panel of $1: 500,000$ geological maps from Morocco to Tunisia could be displayed at the Algiers Congress in 12 large sheets.

The territories of North Africa under French administration did not suffer too much severe damage during the War. The geological infrastructure in 1952 was thus that of the pre-War condition, but strengthened by the arrival of new geologists trained in French universities between 1940 and 1950. They filled up the positions in the geological surveys, as well as those in the administration and the oil companies.

It was relatively easy to organize the 1952 Congress and its excursions. The technical preparation was the work of about a hundred geologists, coordinated by organizing committees in Rabat, Tunis, and Algiers. At the University of Algiers, the staff of the laboratories of Applied Geology (R. Laffitte), Mineralogy (M. Royer), and Geology $(\mathrm{H}$. Termier) prepared the sessions in Algiers, as well as doing the editing of publications and the coordination of the excursions. These were organized by various bodies: the Geological Survey directed by G. Bétier; the Bureau de Recherches Minières (BRMA); some oil geologists, chiefly from the Société Nationale de Recherche de Pétrole 
en Algérie (S. N. REPAL); the Service de la Colonisation et de l'Hydraulique; the Centre for Saharan Research, etc.

In Morocco, the influential Geological Survey, directed by Jean Marçais, grouped together more than thirty geologists in the following sections: Geological Map (G. Choubert); Mineral Deposits (J. Agard); and the Centre for Hydrogeological Studies (A. Robaux). The Bureau de Recherches et Participations Minières (BRPM) and the Société Chérifienne des Pétroles also participated in the organization of the excursions. Several geologists (from the Institut Scientifique Chérifien) and geographers (from the Moroccan Institute of Advanced Studies) - university research bodies - were also involved, as well as some Spanish mining engineers from Spanish Morocco.

In Tunisia, geologists of the Mining Survey and from the Geological Survey (G. Castany) played an essential role. They were assisted by engineers from several petroleum companies (Compagnie des Pétroles de Tunisie, Société Nord-Africaine des Pétroles, SNAP; and above all the Société d'Études et de Recherches des Pétroles en Tunisie, SEREPT).

\section{Preparation of the Algiers Congress}

The Société Géologique de France began the Organization of the Algiers Congress immediately after the London meeting in 1948. The Society's President in 1948 was Professor Pierre Pruvost, from the University of Lille, who was to take over the Chair of Geology at the Sorbonne from Charles Jacob in 1950.

Five organizing committees were established in parallel. The first one, in Paris, had the essential task of garnering financial and political support. The group was presided over by Charles Jacob, and the secretary was Professor Marcel Roubault (from Nancy), whose thesis had been on the petrography of eastern Algeria. The committee in Algiers obviously had the heaviest burden. It was presided over by Marius Dalloni, the (retired) Professor of Applied Geology in Algiers, while the secretary was his successor R. Laffitte. Three other committees were formed in Morocco (with J. Marçais as Secretary-General), in Tunisia (G. Castany, Secretary), and at Dakar in French West Africa. In the absence of academics, these three committees were nominally headed by the mining engineers who administered the geological surveys. They had the essential task of organizing the excursions in each of these countries. Among the three surveys, that of Morocco, important by reason of its noteworthy organization, under the aegis of Paul Fallot, Professor of Mediterranean Geology at the Collège de France (Paris), indicated its wish to have its own special status.

The first task of the Algiers Committee was to establish a "World List of Geologists". It was planned to notify personally as many as possible of the large family of earth scientists about the Congress. The pre-1939 lists were out of date, and that of the London Congress was clearly incomplete. The enormous task of compiling a list led to the production of a volume of 355 pages, listing, by country and then alphabetically, 27,000 people to whom the First Circular was sent. From these, they received an initial positive response of about $10 \%$ to the invitations to attend the Congress. The response to the third and last Circular caused the organizers more concern: only 414 geologists had confirmed their participation by the requested date (31 December, 1951). The uncertainties of the Cold War were raising concerns round the world. This required the organizers to relax the registration date, and by March 1952 the number of registrants stood at 1,259 .

But the eventual state of affairs proved somewhat different from the early indications. The final official figures for Algiers were 2,910 registrations (compared with 2,362 in Moscow in 1937 and 1,778 in London in 1948) with 1,129 actually attending (compared with 949 in Moscow and 1,276 in London). To the Algiers number were added about 300 accompanying persons.

The Congress budget rose to 266 million francs (about 6 million present-day dollars): $65 \%$ came from state subventions (chiefly from France and its various territories); $25 \%$ from 69 societies; and $10 \%$ from the payments of individual participants. Publications accounted for $55 \%$ of the costs; the excursions (preparation and financial assistance to the participants) $30 \%$; the secretariat and administration $15 \%$. As the registrations yielded 10 million francs, the registration fee must have been of the order of 3,000 francs (or about 60 presentday dollars).

\section{The composition of the national contingents}

As usual, geologists from the host country, in this case France and its dependencies, made up the majority, providing about half the participants: out of these 532 people, 262 came from France, 108 from Algeria, 58 from Morocco, 22 from Tunisia, and the remainder from various French territories. The United States, with 114 geologists, were well represented. From 'old Europe', 54 came from Britain, and 67 led by the celebrated Hans Stille came from Germany, which showed the healing of the wounds from the 1939-1945 War. The other countries in Europe with geological traditions were equally well represented, with 43 from The Netherlands, 38 from Belgium, 35 from Italy, 22 from Spain, and 19 each from Switzerland and Sweden. The significant number from Turkey (11) and Yugoslavia (9) should also be noted.

The countries of the Eastern bloc 'sulked', however, France clearly having chosen the camp of the Western democracies. In the end, an official group of 11 Russian geologists suddenly arrived late ... Among the 'satellite' countries, some (Bulgaria and Romania) ignored the Congress altogether. Hungary and Czechoslovakia each had 9 registrations, but only 1 person was actually present. Poland had 16 registrations, from which only 2 persons attended. No one came from the world's most populous country, China, and there were only 3 geologists from Japan. Unfortunately, at the time the geological world was truly divided in two. As for the countries of the 'Third World', they were still not significantly involved in scientific events.

\section{The administrative meetings of the Algiers Congress}

\section{The Preliminary Council Meeting}

The Congress Council was, by statute, made up of the heads of the national delegations (74 present in Algiers), plus 6 members of the Organizing Committee and 3 co-opted members. It proceeded to ratify the nomination of the Board of the new Congress, on the morning of Monday, 8 September, in the University's Salle des Actes. The meeting was chaired by Professor H. H. Read, President of the preceding London Congress.

Professor Jacob, the 'grand old man' of French geology, who had occupied the principal chair of Geology at the Sorbonne (Paris) from 1928 to 1950, was proposed as Congress President. Aged 74 in 1952 , and physically tired, Jacob asked to be assisted in the work by two colleagues: Professor Pruvost (his successor at the Sorbonne and a well-known specialist on the Carboniferous, and having the advantage of being perfectly bilingual in French and English); and Professor Dalloni (who had become an authority on Algerian geological problems). As for the heads of the 74 national delegations, they were, in accordance with custom, all elected as Vice-Presidents.

The vitally important position of Secretary-General was naturally allocated to $\mathrm{R}$. Laffitte, then aged 41 , assisted by his colleague Professor G. Lucas.

An unexpected scene then occurred! G. Bogomolov, head of the Soviet delegation, protested vigorously that only two languages (English and French) were being simultaneously translated, whereas the Congress had six official languages (German, Spanish, Italian, 
and, since 1937, Russian, besides English and French). R. Laffitte replied that this decision, which was the same as the one made at the London Congress, was due to problems of translators; moreover, no Russian geologists had registered for the Algiers Congress at the proper time ...

\section{The Inaugural Meeting}

This meeting was held from 10.30 to mid-day on the same day, 8 September, 1952, in the Great Hall, Pierre-Bordes, in the palace of the Gouvernement-Général of Algeria. Bringing together the 1,300 Congress participants, the hall was decorated with the flags of all the nations there represented. The walls were covered by geological maps, and in particular the new edition of the $1: 500,000$ map of the three North African French countries chiefly involved in the Congress, and the new 1:500,000 map of northwest Africa of Nicolas Menchikoff.

The meeting was opened by Professor Read, who called for the acceptance by acclamation of Charles Jacob as the new Congress President. After Read's address, there followed the President of the Société Géologique de France (L. Barrabé in 1952), Professor Dalloni, who gave an historical exposition of Algerian geology since 1830 , Deputy Bentounès, speaking on behalf of his Muslim countrymen, and finally the Governor-General, R. Léonard.

\section{The Council Meetings}

From Monday afternoon until Saturday the 13th, there was a series of section meetings which will be described later and the Council Meetings. These were enlarged to include all the official delegates of countries or recognized organizations, making up 440 people! The subjects were naturally concerned with the worldwide organization of geology by means of regular congresses.

\section{The problem of communications}

The Third Circular had said that the abstracts would be accepted in any one of the six Congress languages, but for the "convenience of organizational work" it was requested to supply English or French translations for texts that were not in either of these two languages. This request was not followed by the Russian authors, nor by a good many of the German-speaking authors. Nonetheless, a volume of about 175 pages, gathering together about 500 abstracts, was distributed to the participants (and a supplement was printed later for the abstracts that arrived after 1 July, 1952).

A discussion began on this question. Previously, in London, the gathering together of various subjects in several "preliminary symposia" had been suggested (by E. Wegmann, Switzerland, and D. Schneegans, France), the contents or results of which would be discussed during the Congress. This was to avoid a 'scattering' of topics. Other communications (on non-symposium topics) were to be written; but they could be presented orally upon the request of at least five members. This time, in Algiers, H. M. E. Schürmann (The Netherlands) proposed that, following the practice of the Petroleum Congress one should pre-print the texts, a representative from each country being charged with selecting the additional contributions.

The problem was then: given the large number of communications already accepted without real refereeing, was it necessary to adopt 'authoritarian' measures, stipulating the topics that might be discussed and selecting from among the texts offered by the authors? Tactfully, the question was, yet again..., deferred until the next Congress.

With the number of participants at Algiers having exceeded a thousand, one of the organizers, M. Roubault, emphasized that the "'gigantism' that the Congress seemed to be achieving contained the seeds of its own mortality... If the Congress was to stay alive, some changes were required, and the whole problem of these meetings needed to be reconsidered".

\section{The question of an International Union of Geology}

Consideration of this question had been written into the programme, in accordance with the decision taken at the London Congress in 1948. The subject took up the greater part of the time for three animated Council Meetings! The French delegates supported the idea of such a Union: two personalities, often in disagreement, M. Roubault and J. Goguel (Director of the French Geological Survey) were on this occasion in agreement over the question! Goguel had even developed a prepared draft set of regulations, edited along the lines of the rules governing established unions of other scientific disciplines: an independent International Geological Union, a permanent secretariat ensuring continuity between Congresses and the meetings of the interdisciplinary commissions. R. Laffitte, while accepting the separation of the Congress and an eventual Union, deplored the lack of responsible national committees. M. Dalloni recommended that such "national bodies" should be federated in an "international organization" wholly independent of and unrelated to the Congress.

The opponents of the International Union curiously brought together countries that were politically opposed! It will be no surprise that the Soviet's G. Bogomolov was opposed to such a Union, which in his eyes risked being linked with UNESCO. Likewise, he rejected the notion of "national committees" since, in his view, the "government delegations" sufficed. On their side, some Western geologists joined with the Russian point of view but for different reasons. Thomas S. Lovering (USA) was satisfied with the status quo. A. J. Butler (UK), the former Secretary-General of the London Congress, declared that "all that is needed is some geologists, a little money, and plenty of good will; if a small country wishes to have a Congress, it can do so". In the same spirit, W. H. Butcher (USA) declared that "a secretary and two or three stenographers" would be "sufficient to ensure the continuity of the Congress".

Thus great confusion reigned at the beginning of these debates. On 10 September, the Council determined that the Congress, such as that holding its meeting in Algiers, must continue. A motion in favour of the establishment of national geological bodies received 59 votes in favour, 33 against, out of 446 registered voters!

Trying to help, two geologists endeavoured to get the project back on the rails. Professor Read suggested that a responsible geologist or body be so designated in each country. And Professor R. C. Moore (USA) proposed the establishment of a "working commission" to organize an "international geological council".

Another vote was held on 12 September. Read's proposal of the establishment of national committees was adopted by 246 votes. On the other hand, 203 votes were opposed to the institution of an International Union, which was thought to be unnecessary.

The time was not yet ripe for the creation of the IUGS.

\section{The choice of the meeting place for the XX International Geological Congress.}

Candidate hosts were not crowding one another! The proposal of India, made in London in 1948, was not renewed: the country had meanwhile become independent and was suffering from political unrest. Her delegate, B. C. Roy, had to declare at the closure of the Algiers Congress: "I would like to add that although it has not been possible to extend the invitation to the next Congress in India, I will ... explore the possibilities of holding the XXI Session of the Congress in India". In the event, the XXII Session was held in New Delhi in 1964. We shall see that, finally, Mexico, after persistent persuasion, agreed to host the XXI Session of the Congress. 


\section{The scientific meetings in Algiers}

These were held in the rooms of the University of Algiers (rue Michelet, subsequently the rue Didouche Mourad), between the hours of 8.30 a.m. and 4.00 p.m., which made possible the Council Meetings at the end of the afternoons. The "studious ambience" was described by the Journal d'Alger as follows: "The XIX Session of the International Geological Congress pursued its work in an atmosphere filled with smoke by the tobacco from all corners of the world, and in the enthusiastic atmosphere of working together and comparing ideas".

The provisional programme listed more than 400 contributions. Reckoning from the abstracts received before 1 July, the languages used were in the following proportions: French 53\%, English 30\%, German $8 \%$, Spanish 5\%, Italian and Russian 2\% each.

Even if the communications presented at the Congress were rarely original, they nevertheless reveal the topics that were fashionable and the divergences between different schools of thought. They were expensively printed in 21 volumes on 'Alfa' paper (alfa being a grass from the high Algerian plateau).

In Section 1 ('Precambrian'), some of the significant contributions were concerned with the connection between Scotland and Ireland (J. G. C. Anderson, UK); the Moroccan 'Anti-Atlas' or southern Atlas Mountains (G. Choubert, France); and the Gulf of Suez zone (H. M. S. Schürmann, The Netherlands). L. Cahen (Belgium) and A. M. Macgregor (Rhodesia) sought to distinguish the successive orogenies of the southern Sahara, making use of some of the first radiometric ages for that area.

In Section 2 ('Palaeozoic'), W. J. Jongmans (The Netherlands) noted the Euro-American characteristics of the flora of the Upper Carboniferous, while P. Hupé (France) discovered in the Moroccan Lower Cambrian some Asiatic trilobites in the milieu of Euro-American species.

Section 3, devoted to the 'Mechanics of Rock Deformation', offered some rich and interesting contributions: the role of granitic bodies in the deep nappes during the Alpine Orogeny (W. K. Nabholz, Switzerland); the fabric of marbles (F. J. Turner, USA); schistosity (P. Fourmarier, Belgium); the problem of the Rift Valley (B. B. Brock, South Africa); physico-chemical factors in rock deformation (J. Goguel, France). At this time, when nappe tectonics was banned by Moscow as a product of 'bourgeois science', the Pole A. Tokarsky had the courage to describe the flysch nappes of the Carpathians, revealed by deep bore-holes.

In Section 4 ('Submarine topography') some significant work was reported on submarine canyons (F. B. Shepard, USA) on the rates of sedimentation in deep sea water (H. Petterson, Sweden), and J. Bourcart (France) furnished the first map of the French Mediterranean bottom littoral

The Fascicule for Section 5, on 'Prehominids' was, apart from a paper by G. von Koenigswald (The Netherlands) on Pithecanthropus and Australopithecus, devoted to a "Catalogue of Fossil Hominids", which brought together the contributions of 35 specialists from around the world.

Section 6, 'The genesis of veined rocks', was related to the memorable controversy between the magmatists (such as E. Niggli, Switzerland) and the 'solidists' like M. Roubault and the engineer R. Perrin (France), who maintained that granitic veins resulted from replacement in the solid state, in a manner analogous to the diffusion of ions in metallurgy.

In Section 7, on 'Deserts ancient and modern', D. A. Holm (USA) showed some splendid photographs of 'dome-shaped dunes' at Nadj in Saudi Arabia. Various other North Americans (A. D. Howard, A. T. Benjamin, F. K. Morris) treated the formation of pediments in arid regions. K. C. Dunham (UK) argued strongly for the red colour of the New Red Sandstone being due to reworking from a tropical pedological cover.

Section 8, on 'Hydrogeology of arid regions', generated many articles, mostly on particular regions such as Lower Sahara for example (R. Karpoff, France). G. Bogomolov made a plea for "geol- ogy and hydrogeology contributing to the transformation of Nature in the USSR", citing the irrigation of saline lands!

'The genesis of iron beds' (Section 10) was considered in various countries, particularly in what was then called 'Precambrian' (M. Alia and A. Arribas, Spain) of the Spanish southern Sahara, now Mauritania. The great wealth of these deposits has subsequently been recognized.

The abundance of 'Phosphate of lime' in the Eocene of Morocco and Tunisia justified the holding of Session 11. Several papers noted their relative abundance of uranium. Under the head 'Applied geology' (Economic Geology), Section 12 was chiefly devoted to mineral beds. The metallogenic theory of $\mathrm{H}$. Schneiderhöhn (Germany) on "regenerated layers" (thermal waters dissolving the material of older layers) found some supporters, such as E. Raguin (France) for the Moroccan $\mathrm{Pb}-\mathrm{Zn}$ deposits or the Red Beds.

Section 18 ('Miscellaneous Questions in General Geology') claimed to be a complete tangle of a Section, and the number of communications required the printing of three fascicules. New geological maps of French Guiana (B. Choubert, France) and New Caledonia (J. Avias, A. Arnould, and P. Routhier, France) were presented. H. D. Hedberg (USA) recalled the principles of "stratigraphic chronology", arguing for the separation of litho- and bio-stratigraphy, the stratigraphy of stages depending on type sections: we were at the time when the notions of 'formations' familiar in Anglo-Saxon countries, contended with that of stages, as used in Continental Europe.

J. Bourcart (France) defended, against his critics, his theory of "continental flexure" at the edge of oceanic areas. A. R. Lamego (Brazil) cited the Brazilian coastal structure, with collapses towards the Atlantic at the end of the Cretaceous, which depended on the hypothesis of continental drift, which had surprisingly become obsolete at that period.

The singular metamorphism of the scapolite minerals of the Mesozoic terrains of the Pyrenees (J. Ravier, France) was correctly dated to the post-Albian and pre-Cenomanian, which afterwards was vigorously but erroneously contested. One topic had the honour of being mentioned in the press: the announcement (by R. Karpoff, France) of the discovery of the crater, supposedly meteoritic, of Talemzane east of Laghouat, in Algerian Sahara, of diameter nearly $2 \mathrm{~km}$. It was (in 1952) considered to be "the second crater of this kind in the world" by size "ahead of the Meteor Crater of Arizona".

In "The oil fields of Mesogean regions" (Section 14), M. Tenaille and J. J. Burger, Algeria) recalled the discovery in 1914 of the first, but small, oil-bearing field of Tliouanet, in Oranie (western Algeria). If one believed the Journal d'Alger, the account of the petroleum geology of Mexico (E. J. Guzman et al.) was applauded for almost ten minutes! This ovation was perhaps related to the possibility of the next Geological Congress being held in Mexico.

Section 15 ('Palaeovolcanology') provided the occasion for several preliminary accounts of sub-marine basalts, formed at depth, and their relationship to orogenesis. J. H. Brunn (France) spoke on the "ophiolitic eruptions" of the "geosynclinal volcanism of the Jurassic" in Greece. L. Dubertret (France) described the basalts and "green rocks" of the Middle East as being emplaced "in deep water". And M. Vuagnat (Switzerland) treated "the role of sub-marine volcanic flows in ancient mountain chains". It should be recalled that knowledge of the actual oceans, an essential source of information for the future 'new global tectonics', was but 'stammering' in its infancy.

\section{Specialized Commissions}

The International Committee for the study of clays (Fascicule 18) facilitated discussion between the proponents of an almost wholly detrital origin for the clay minerals in the marine sediments (A. Rivière, France) and those who supported the importance of epigenetic replacement (G. Millot, France). R. C. Moore (USA) put forward three recommendations on the classification and terminology in pal- 
aeontology - principles that would soon be utilized in his celebrated Treatise on Invertebrate Paleontology.

The Association of African Geological Surveys presented some varied work (Fascicules 20 and 21). Several communications were received from Angola, in particular on a new geological map (F. Mouta, Portugal), and an illustration of Hedberg's recommendation by the definition (which subsequently became classic) of the Mesozoic stratigraphic formations in Tunisia (P. F. Burollet, France). As for Th. Monod (France), he gave a preliminary account of some "circular or crater-form occurrences in the western Sahara".

A Symposium on Gondwanaland research warranted an important volume, where various Gondwana Series were described. C. Teichert (a German geologist then working in Australia) gave a noteworthy "History of the Gondwanaland Concept", conceived by $\mathrm{J}$. Marcou in 1860, but established in 1875 by H. Blanford and developed by M. Neumayr in 1887, before the great Austrian geologist E. Suess codified the term in 1885-1888.

Finally a Congress tradition required the preparation of an inventory of mineral resources. In Algeria, work on the "World's Iron-bearing Strata" (coordinated by F. Blondel and L. Marvier, France) revised the data of the Stockholm Conference (1910) (Sundquist and Nordlund, 2004). Two volumes (1,234 pages, plus atlas) treated the deposits of the whole world. With the exception of Hungary and Yugoslavia, the countries of what was at the time the Soviet bloc and China declined to communicate their data on minerals thought to be of strategic importance.

\section{The cruise excursion}

This spectacular event preceded the holding of the Congress in Algeria. It took place between 24 August (departing from Marseilles) and 7 September, 1952 (arriving in Algiers) on the steamship Champollion belonging to a company called Messageries-Maritimes. The cost was 45,000 francs (about $\$ 900$ present-day dollars) per person. Professor Roubault was excursion director and the future Professor Jean Hilly was deputy director. Nearly 300 persons were on the passenger list, among whom were 80 family members of the Congress participants. The largest numbers of participants were French (74) and North American (54). Important contingents came from Germany (23), Italy (21), Belgium (20) and Great Britain (18). The Soviet group (11) was accompanied by a 'minder' ...

The calm atmosphere and the lengthy journeys favoured contacts between the geologists of different nationalities and allowed useful discussions between the numerous delegation leaders present on the cruise. After departing from France and a crossing of two days the steamship reached the coast of Africa, along which it then sailed. The landings generally lasted two days; the ship served as a hotel, and each day on land was devoted to an excursion, with eight coaches and travelling deep into the inland parts of Tunisia and then of Algeria. Stops were made at Tunis (excursion from Bizerte to Djebel Zaghouan) to Bône (Annaba) (the ancient massif of Edough and a crossing of the Tell Mountains as far as the iron mine of Ouenza), to Philippeville (Skikda) (the ancient massif of Collo and the neighbourhood of Constantine), and further to Djidjelli (Jijel).

The Champollion reached Bougie (Bejaia), from which three excursions examined the Kabylie des Babors mountains and the eastern part of Great Kabylie. Passing Algiers, after a night and a day at sea, the travellers arrived at Oran, and made two circuits in the coastal regions to the west of the town. Finally, turning east again, on Sunday morning, 7 September, the participants enjoyed the dazzling sight of Alger-la-Blanche - the end of the journey.

Besides reading the ample guide book of 129 pages, the passengers were able to listen to several talks, of which two (by M. Roubault and J. Flandrin) gave a picture of what was then known of the geology of Algeria and the structure of the coastal regions. Certainly it was a scientific voyage, but also a real cruise!

The only future cloud to the delightful picture: a year later the Champollion sank off the coast of Lebanon, in front of Beirut ...

\section{The excursions of the Algiers Congress}

In addition to the cruise, 57 options were available to the Congress participants and 44 actually took place: 17 before the Algiers meeting, 22 immediately afterwards and 5 in October in the very hot southern region. Their lengths and objectives varied according to the areas visited. They were substantially subsidized by the Congress budget.

In Algeria the trips were from 7 to 13 days. Most of them (10) were concerned with the coastal chains or the Saharan Atlas. Others visited sites that were concerned with applied geology. Twentyseven printed regional monographs were distributed for the occasion. The most significant ones were concerned with the central Sahara (M. Lelubre), Djurdjura Range (J. Flandrin) and the Algiers region (L. Glangeaud et al.).

The two excursions concerned with hydraulic management (dams) were accompanied by numerous small booklets, which together made up a work on Geology and Water Problems in Algeria ( 2 vols). Similarly, the diverse areas of Tunisia and the mineral resources of this country were the object of 7 monographs (by G. Castany et al.). They illustrated the four regional excursions (10 to 14 days) and those on water resources.

For Morocco, the size of the country warranted 14 excursions. Some, which were repeated, crossed the whole country from north to south, or were concerned with the large orogens of the Rif or Atlas Mountains. Also there were thematic excursions on the petrography, mineral geology, hydrogeology, and geomorphology of Morocco. The organizing committee in Rabat showed its originality. Besides the substantial guidebooks (15) for the excursions, 5,000 to 6,000 copies of important syntheses of Moroccan geology were printed: on mineral deposits, mineral industry, geomorphology, hydrogeology, applied geology for major engineering works, the geology of Morocco (with a detailed description of the Anti-Atlas by G. Choubert).

The last five excursions were held in October, 1952. The journeys (which were repeated) covered central Sahara (Hoggar or Ahaggar) and lasted 18 days. There were also voyages to Senegal, Guinea, and Mauritania. One of these tours, led by the celebrated Sahara naturalist Théodore Monod, was devoted to the Palaeozoics of Mauritania, and lasted 25 days, with the participants travelling on the backs of camels!

\section{Conclusion of the Algiers Conference}

A general assembly of all Congress participants was held on Saturday, 13 September, 1952. Several questions were raised: the state of progress of the Lexique stratigraphique international; and the editorial situations for the international geological maps of Europe, Africa, and the World. The results of the specialist commissions were recorded, as well as the announcement of the creation of AZOPRO (Association pour l'étude des ZOnes PROfondes) - the association for the study of the lower part of the Earth's crust, led by P. Michot (Belgium). The establishment of new Congress sections in Mineralogy, Petrography, Geochemistry, and also Micropalaeontology was requested.

Speaking on behalf of the views of the participants, Th. Monod and J. Flandrin argued that general oral talks on geology should be introduced in future conferences. The example of the London Congress (1948), where E. Bailey, in particular, had presented a notable exposition of "The structural geology of Scotland" had not been followed in Algiers; but in 1952 no clear structural picture was generally accepted for North Africa. On another project, F. R. S. Henson proposed the indexing of geological bibliography, country by country.

The closing ceremony of the Algiers Congress was held on the afternoon of the same day. When the French Minister of National Education (André Marie), accompanied by the Governor General 
Léonard, entered the large Pierre-Bordes hall, the Marseillaise broke out, played by the band of the Algiers garrison. For reasons of time, only the heads of delegations of countries that had hosted the Congresses since their foundation in 1878 were permitted to pronounce their ritual allocutions. However, the Indian representative (B. C. Roy) was able to speak for the Asian countries that had not previously been at the international congresses.

President Jacob expressed the Congress participants' satisfaction that the sojourn had been favoured by good weather. The announcement, confirmed by telegram, of the acceptance of the XX Congress by Mexico was received with relief by the organizers of the Algiers Congress. In the closing address, the Minister, André Marie, expressed his hope that the participants had been able to see and photograph all the sites and the regions where they had travelled, thus ironically recalling a question posed by certain Soviet delegates on their arrival in Algiers.

Shortly after the closure on the meeting, the Mayor of Algiers gave a reception to the participants in the municipal rooms. The crowning event of the day for the official delegates and the principal Congress organizers was in the evening: a banquet, washed down with Algerian wines and champagne, held at the famous Hotel SaintGeorge on the heights of Algiers.

\section{Lessons from the Algiers Congress}

In sum, the Algiers Congress, as regards material organization, was a great success. Apart from some francophone participants, North Africa was for many, up until 1952, a region that had been ignored by geologists. Thanks to the many long excursions, however, the participants realized that the geological study of its several countries was well under way. The researches undertaken by numerous young geologists since the end of World War II had largely contributed to this development.

The 1952 Congress participants could not, however, know of the major developments in North African geology that were to occur in the following years. A tectonic conception was only generalized after 1955 , and gradually became accepted, with the alpine structure having large thrust-sheets (nappes de charriages) for the whole of the coastal Atlas Mountains, from the Rif of Morocco to the Kroumirie of
Tunisia (the future Chaîne Maghrébide). On the economic side, the first major deposits of petroleum (Hassi Messaoud) and gas (Hassi R'Mal) were discovered in the Algerian Sahara in 1956.

Since the countries of North Africa have gained their independence, geological investigation has been steadily and harmoniously realized between the geologists on the north side of the Mediterranean and their young colleagues in Algeria, Morocco, and Tunisia. And despite the progress made since 1952, so many tragic events have supervened that many of the documents printed in Algiers in 1952 still retain their significance and interest. They take up 1.5 metres of shelf space in geological libraries!

The Algeria Congress was thus crowned by an exceptional publication success, for which the organizers should be credited (in particular the future professors G. Busson, Y. Gourinard, and Ch. Bär). It 'perennialized' the memory of the exceptional event, which preceded the end of the French presence on the northern edge of the African continent.

The present writer, who made a modest contribution to the Congress by co-leading an excursion to Kabylia, has chiefly used printed documents in preparing this memoir. $\mathrm{He}$ has received valuable advice from his former 'Algerian' colleagues, G. Busson and J. Hilly. However, many documents have unfortunately disappeared since the tragic events in Algiers in 1961-1962. And the chief player at the Congress, Secretary-General Robert Laffitte, died in 2003, and could not be consulted.

The author is pleased to express his thanks to Professor David Oldroyd, the past Secretary-General of INHIGEO, for translating this paper. The original French text appeared in Travaux du Comité Français d'Histoire de Géologie, v. 18, ser. 3, 165-180 (2004).

\section{References}

Malinovsky, E. E. 2004. Three sessions of the International Geological Congress, held in Russia and the USSR $(1897,1937,1984)$ : Episodes, v. 27, 101-106.

Sundquist, B. and Nordlund, C. 2004. Science and honour: The 11th International Geological Congress in Stockholm 1910: Episodes, v. 27, 284-292.

Trümpy, R. 2004. The 18th International Geological Congress, Great Britain, 1948: Episodes, v. 27, pp. 195-198.

\title{
CALL FOR PAPERS
}

Episodes is the quarterly science and news journal of the International Union of Geological Sciences (IUGS). It focuses on the publication of results of scientific research and other information addressing issues of interest to the global earth-science community. Special emphasis is given to topics involving geological aspects of population growth and economic development and their resulting impacts on or implications for society. As the principal publication of the IUGS, Episodes also carries information about IUGS scientific programs and activities to the extent necessary to communicate effectively with the worldwide IUGS constituency.

Contributions of the following types of manuscripts are here solicited:

- review papers

- scientific articles

- conference reports

- news and views

- letters to editor

- book reviews

- information on training courses (especially those geared to participants from developing countries)

- noteworthy new publications, including national or regional geologic maps

Please address all contributions to:

\author{
The Editor \\ Episodes \\ P. O. Box 823, 26 Baiwanzhuang Road \\ 100037 Beijing, CHINA \\ Tel: +86-10-6832 0827, +86-10-68329084 \\ Fax: +86-10-6832 8928 \\ E-mail: episodes88@yahoo.com
}

